\title{
The Effectiveness of Quantum Learning Model toward Eight Grade Students' Reading Skills in SMP N 12 Bintan
}

\author{
Raudah $^{I}$ \\ ${ }^{1}$ Corresponding author, SMP N 12 Bintan, Indonesia; \\ raudah_zein@yahoo.co.id
}

\begin{abstract}
This study aims at analyzing the implementation of Quantum learning model for EFL learners at SMP N 12 Bintan, Kepulauan Riau province. Urged by the factual situation that lack of students' reading ability, the chosen model was applied in the form of classroom action research. The subject of the study is 31 of eight grade students. The result showed the application of the Quantum learning model improves students' ability to read text. This is indicated by an increase in reading skills from pre-cycle which only averaged 75.23 to 78.52 in the first cycle, while the percentage of completeness increased from $35 \%$ to $84 \%$. In cycle II, with the improvement of Quantum learning accompanied by encouragement from teachers and guidance in groups to actively ask questions, feedback, reinforce, and divide heterogeneous groups, the average score increased to 82.29 , and the percentage of completeness increased to $100 \%$.
\end{abstract}

Keywords: Classroom Action Research, Reading skills, Quantum Learning Model

\section{Introduction}

\subsection{Background of the study}

In addition to three other language skills, reading is one of the most significant language skills. This is because reading is a means of learning other desirable worlds so that people in reading material can expand knowledge, have fun, and explore written messages. Reading though is not an easy job. Reading is a process that can be developed using techniques which fit the reading purpose.

Rahim (2007:3) states that the process of translating written symbols into sound is to $r$ ead as a visual process. Reading as a thought process includes word recognition, literal co mprehension, interpretation, critical reading and creative reading. Reading as a linguistic method, the schemes of the reader help him construct meaning, while phonological, semantic, and syntactic characteristics help him communicate and understand messages. The metacognitive process involves the planning, rectification, monitoring and assessment of a strategy. At this point, the reader defines the task of reading to establish a suitable reading method, tracks his comprehension and evaluates the results. Reading is an interactive practice, according to Somadayo (2011: 5), to select and interpret the meanings found in written content. Besides that, reading is also a process that is carried out and used by the reader to obtain the message to be conveyed by the writer through the media of words / written material. 
One key to student's success is the ability to read. In fact, many students are still not enjoying what they are reading. Abdurahman (1996: 171) argues that many students can read a reading material fluently but do not understand the content. This decreases interest in reading, as reading is considered a boring task. Based on these phenomena, reading activities must be followed by an understanding of what is read, in other words, a reading comprehension must exist.

As the results of measurements made by PISA or the Program for International Student Assessment in 2006 (Fuady, Amir, Sumarwati, and Slamet Mulyono, 2012: 1), which is a survey of reading literacy in junior high school students from various countries, shows the reading ability of Indonesian students in the order of 48 out of 56 countries. This is the lowest position for countries in the Southeast Asian region. The low ability of students to be a clue to the weaknesses and difficulty learning to read comprehension.

The same problem also occurs in students of class VIII.3 SMP 12 Bintan, namely students have low ability to read texts. This is evident from the results of students' reading tests on English lessons which show that $35 \%$ of students have adequate ability (achieving a minimum score of 75).

Based on the results of interviews with students obtained information that students' reading difficulties stem from difficulties in understanding the main thoughts or main ideas in reading, in addition to the low interest and motivation of students in learning to read. From the teacher's observations obtained information about the causes of students' difficulty in understanding the contents of the reading, namely students are less able to select the parts that are important and less important. They pay the same attention to all passages of reading, so that the time required is longer and the difficulty in identifying the main ideas.

Reading learning that occurs in class is usually done by the teacher giving the task to students to read reading material. Before the activity is carried out, the teacher talks about information that is considered important in relation to what students have to do. Furthermore, students conduct discourse reading activities from beginning to end followed by answering questions related to the content of the discourse. If students do not understand the content, the reading is repeated as before. The learning implementation shows that students are not given the opportunity to carry out reading activities through the process that should be, namely the preparation phase of reading, the reading stage, and the stage of follow-up activities. The reading activities that students have been through are directly at the reading stage and followed by the follow-up activity stage.

To improve students' ability to read text, there are several learning models that can be applied in learning. One learning model that can be used in learning to read is the Quantum learning model. This learning model is known by removing barriers that block the natural process of learning through deliberate efforts. Removal of barriers to learning which means streamlining the learning process and emphasizing learning activities that are fun for students.

Presentation in the Quantum learning model is an ideal learning model, because it emphasizes collaboration between students and teachers to achieve common goals. This learning model is also effective because it allows students to learn optimally, which in turn will be able to significantly enhance student learning and learning outcomes.

The presentation of learning in Quantum follows the steps of the procedure which is abbreviated TANDUR in Indonesian language (Bobby DePorter, 1999: 10). Step 1) Grow, meaning that a teacher in teaching must be able to arouse students' interest in attending various kinds of lessons, so that with existing interests, learning will be able to run smoothly. 2) Natural, it means that a teacher in teaching must be able to create general experiences that can be understood by students. The teacher in teaching gives examples of events that have 
been seen by children everyday. 3) However, the meaning of a teacher in teaching using words that are easy to understand, easy strategies to do in delivery with multimethods and multimedia. 4) Demonstrate, meaning teachers in teaching provide opportunities for students to show that they know, meaning teachers in teaching use teaching aids to demonstrate the material being taught, so students will easily remember the contents of the message delivered by the teacher. 5) Repeat, meaning the teacher in teaching can show an easy way to repeat the material that has been learned. For example, by providing a summary of what was taught earlier. 6) Reward, meaning that a teacher in teaching can give recognition to students' efforts to complete assignments and to acquire skills and knowledge. Classes can be a home for students, not only open to feedback, but also a place to learn to recognize and support others, where they experience joy and satisfaction, give and take, learn and grow.

From the results of reading skill data in class VIII.3, it can be seen that the learning model used by the teacher can also affect students ' reading ability. This inspired researchers to enhance the learning process through classroom action work by taking the title "the Effectiveness of Quantum Learning Model toward Eight Grade Students' Reading Skills in SMP N 12 Bintan".

\subsection{Literature review}

Bobby DePorter, 1999 (in Udin Saifudin Sa'ud, 2008: 125) thinks that the Quantum learning method is in accordance with the workings of the human brain and human learning in general with the SuperCamp model developed with friends in the early 1980s, the principles and the Quantum learning model determines its shape. Quantum learning is based on a foundation of pleasant contexts and joyful situations.

Bobby (in H. Yatim Riyanto, 2009: 180) uses techniques and other techniques because they are in harmony with the workings of your brain, in your best ways, those techniques have been tested to all succeed, meaning that quantum learning also works. Furthermore Udin Saifudin Sa'ud (2008: 127-128), the term quantum is borrowed from the world of physics which means interactions that convert energy into light. That is in quantum learning, changing various kinds of interactions that occur in learning activities. These interactions change the abilities and natural talents of teachers and students to be a useful light for their progress in learning effectively and efficiently. In addition, the process of changing learning is still with all the nuances, the inclusion of everything related, interactions and differences that maximize the moment of learning, focus on relationships in the classroom environment, all of which are things that underlie Quantum learning. There are two main concepts used in Quantum learning in order to bring the energy of teachers and students into learning light, namely: accelerating learning through deliberate efforts to erode traditional learning barriers and learning facilities which means facilitating learning.

According to Darmiyati Zuchdi and Budiasih (1996/1997: 49) defining reading is one type of written language skills that are receptive. Called receptive because by reading, a person will be able to obtain information, gain knowledge and knowledge as well as new experiences. Thus, reading becomes an important element for the development of human knowledge.

Based on the definitions that have been described by the figures above, it can be concluded that reading is a complex activity involving physical and mental activities aimed at understanding the contents of the reading in accordance with the stages of cognitive development and using some of its knowledge to get messages or information from an writing or written language, so that it makes meaningful and beneficial to the reader. Reading not only speaks the written language or language symbols, but also responds to and 
understands the contents of written material. Thus, reading is essentially a form of written communication.

The goal of teaching reading is to achieve reading comprehension. It occurs when the readers read information from the text and recall their knowledge or experience related with text to construct meaning (Yonata, 2018). Therefore, the implementation of Quantum here is to facilitate students to comprehend the reading text.

\section{Method}

The current study implements classroom action research (CAR). The research design used in this study is proposed by National Education Department (2011). The procedures in this design are as follow:

a. Action Planning

In the first cycle the planning is arranged based on the initial observation reflection, the planning cycle II is arranged based on the first cycle, and so on until the objectives of the study are achieved with satisfactory results. At the planning stage it is decided what will be the focus of learning, strategies, models that will be used.

b. Implementation of Actions

In carrying out this action the researcher will carry out in accordance with the plans that have been prepared and focused on the purpose of doing research, namely improving the ability to read the text. This action uses the Quantum learning model.

c. Observation / Data Collection

1) The teacher monitors the situation of students in the learning process and the implementation of teaching and learning activities by taking notes by the teacher himself.

2) The teacher gives an evaluation with a performance test.

d. Reflection

Carry out analysis and reflection on the results of the assessment and observation. If the first cycle has not given the expected results then proceed to the second cycle.

\subsection{Respondents}

The respondents are 31 students from grade eight in SMP N 12 Bintan. The total respondents are 12 male and 19 female students participated in the study. They are in the second semester of 2018/2019 academic year.

\subsection{Instruments}

In collecting the data, the instruments used in this research are reading aloud test and observation sheet. The instrument for test is presented in table 1 and the guidance in scoring for students' reading ability is provided in table 2 .

Table 1. Reading Test Instrument

\begin{tabular}{lllllll}
\hline & Aspects & \multicolumn{4}{c}{ Score } & \multirow{2}{*}{ Total } \\
\cline { 3 - 5 } No & & 5 & 4 & 3 & 2 & 1 \\
\hline 1. & Reading fluency & & & & \\
\hline 2. & Accuracy of intonation & & & \\
\hline
\end{tabular}


3. Clarity of articulation

4. Clarity of sounds in Reading

5. The accuracy to pause/stop reading

6. The suitability of facial expressions with the contents of the text

Average Score:

Table 2. Reading Test Indicators

\begin{tabular}{|c|c|c|c|}
\hline No & Aspect & Indicator & Score \\
\hline \multirow{5}{*}{1.} & \multirow{5}{*}{$\begin{array}{l}\text { Reading } \\
\text { fluency }\end{array}$} & Reading is very smooth and does not experience obstacles & 5 \\
\hline & & Reading smoothly and very little experience & 4 \\
\hline & & Reading is quite smooth but has a few obstacles & 3 \\
\hline & & Reading is not fluent and difficult to understand & 2 \\
\hline & & Reading less smoothly and still faltering & 1 \\
\hline \multirow{5}{*}{2.} & \multirow{5}{*}{$\begin{array}{l}\text { Accuracy of } \\
\text { intonation }\end{array}$} & The spoken intonation is very clear, not monotonous or flat & 5 \\
\hline & & The tone is pronounced right, not monotonous or flat & 4 \\
\hline & & The intonation is quite precise, rather monotonous or flat & 3 \\
\hline & & $\begin{array}{l}\text { The intonation spoken is not quite right, rather monotonous or } \\
\text { flat }\end{array}$ & 2 \\
\hline & & $\begin{array}{l}\text { The intonation spoken is not quite right, it seems monotonous or } \\
\text { flat }\end{array}$ & 1 \\
\hline \multirow{5}{*}{3.} & \multirow{5}{*}{$\begin{array}{l}\text { Clarity of } \\
\text { articulation }\end{array}$} & The articulation spoken is very clear & 5 \\
\hline & & Clear articulation & 4 \\
\hline & & The spoken articulation is quite clear & 3 \\
\hline & & The articulation spoken is unclear & 2 \\
\hline & & The articulation is unclear & 1 \\
\hline \multirow{5}{*}{4.} & \multirow{5}{*}{$\begin{array}{l}\text { Clarity of } \\
\text { sounds in } \\
\text { Reading }\end{array}$} & Reading with volume is very clear and sounds loud & 5 \\
\hline & & Read with clear volume and loud voice & 4 \\
\hline & & Reading at a volume is clear enough, but not so loud & 3 \\
\hline & & Reading at a volume that is not clear and not so loud & 2 \\
\hline & & Read with a weak volume, unclear, and not loud & 1 \\
\hline \multirow{5}{*}{5.} & \multirow{5}{*}{$\begin{array}{c}\text { The accuracy } \\
\text { to pause/stop } \\
\text { reading }\end{array}$} & The pause/stop is very precise & 5 \\
\hline & & The pause/stop is correct & 4 \\
\hline & & The pause/stop is quite appropriate & 3 \\
\hline & & The pause/stop isn't quite right & 2 \\
\hline & & The pause/stop is incorrect & 1 \\
\hline \multirow{5}{*}{6.} & \multirow{5}{*}{$\begin{array}{l}\text { The suitability } \\
\text { of facial } \\
\text { expressions } \\
\text { with the } \\
\text { contents of } \\
\text { the text }\end{array}$} & $\begin{array}{l}\text { Facial expressions are very compatible with the contents of the } \\
\text { text and not excessive }\end{array}$ & 5 \\
\hline & & Facial expressions according to the contents of the text & 4 \\
\hline & & $\begin{array}{l}\text { Facial expressions are quite in accordance with the contents of } \\
\text { the text and are somewhat excessive }\end{array}$ & 3 \\
\hline & & $\begin{array}{l}\text { Facial expressions do not match the contents of the text and are } \\
\text { rather excessive }\end{array}$ & 2 \\
\hline & & $\begin{array}{l}\text { Facial expressions are not in accordance with the contents of the } \\
\text { text and excessive }\end{array}$ & 1 \\
\hline
\end{tabular}

\subsection{Data Analysis}

Data from the results of this study were analyzed using descriptive analysis. Quantitative data is analyzed by finding mean, median, mode, making class intervals and 
presenting in the form of tables and figures. This research is classified to be successful and not proceed to the next cycle if $85 \%$ or more students have achieved mastery learning and with an average value of at least 75 .

\section{Finding and Discussion}

The ability to read students' texts initially showed an average value of 75.23 . The value obtained by this student is in accordance with the KKM value of English language learning which is 75 . But the number of students who have finished learning is only 11 students $(35 \%)$. Classically the mastery learning value set is $85 \%$. The results of the teacher's own reflection, which causes the low ability to read students is, during the teaching and learning process takes place the class focuses on the teacher as the main source of knowledge and the teacher also has not applied various teaching models to change the teaching paradigm into a learning paradigm.

\section{First Cycle}

The observations in the first cycle, which are listed in the table above, show 26 students who have finished reading text lessons, 5 students who have not completed the 31 students who are in class VIII.3 SMP Negeri 12 Bintan

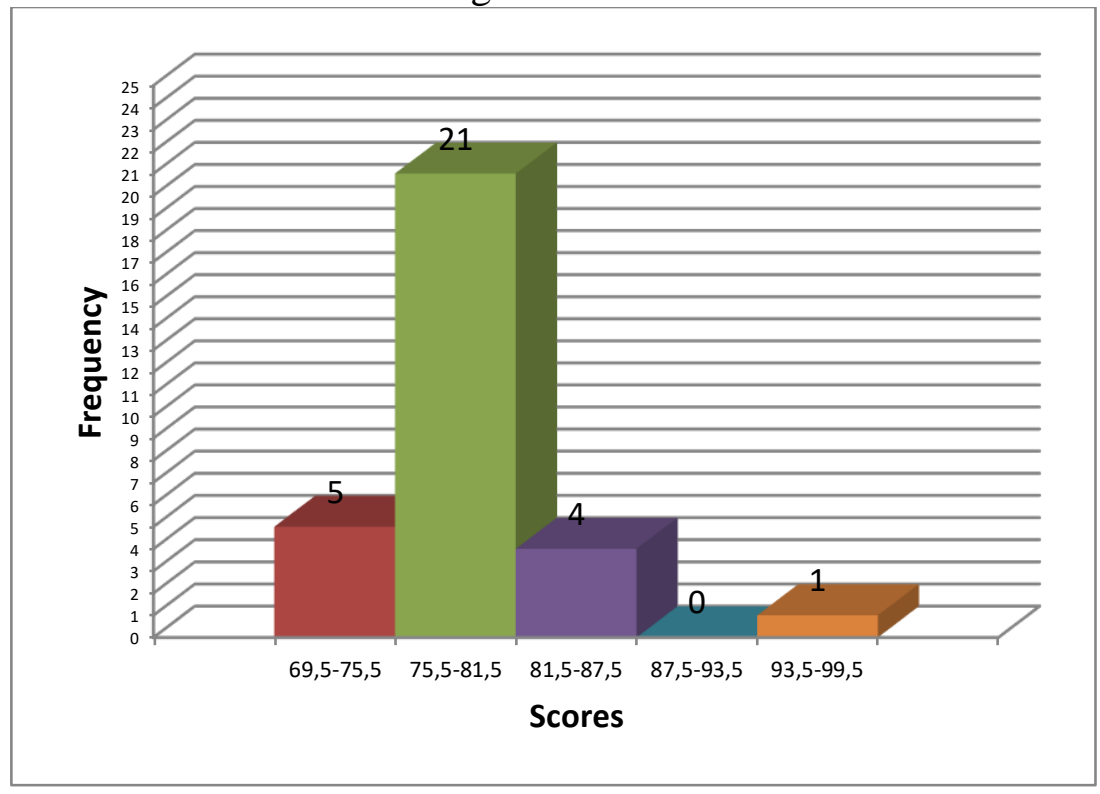

Based on the notes that researchers did, in the first cycle can be seen an increase in student learning creativity. This improvement is marked in the behavior of students in the classroom and mastery of the material. When learning takes place, students dare to express their opinions either by asking questions or expressing ideas. Students become able to search, find and answer the subject matter by themselves. When learning takes place students feel happy, excited and enthusiastic to participate in learning activities. Students look more enthusiastic, relaxed and do not feel bored when learning takes place. Students no longer feel afraid in expressing their ideas and can express themselves freely. The concentration of students in learning increases because students are given a problem that must be solved.

However, the results of the analysis showed a slight shortcoming, namely the ability to read students' texts was in accordance with the minimum completeness criteria of this lesson which was 75 , but the percentage of completeness was not yet $85 \%$. The shortcomings that 
exist from the implementation of the first cycle of action are: there are some students who are good at dominating in presenting the results of the discussion, while other students still do not dare to present the results of the discussion because of fears of not being able to answer questions raised by other groups.

The next improvement will be about repetition of how to understand the subject matter listened to then dare to express thoughts and feelings in oral and written form, the teacher sometimes takes over the course of the discussion while providing reinforcement, testing one student with other students with direct questions so as not to only smart students dominate the learning process, but all students are expected to achieve satisfying results.

\section{Second Cycle}

The results of observations in the second cycle, which are listed in the table above show that all students have finished reading text lessons, of the 31 students in class VIII.3, semester II achieved $100 \%$ completeness.

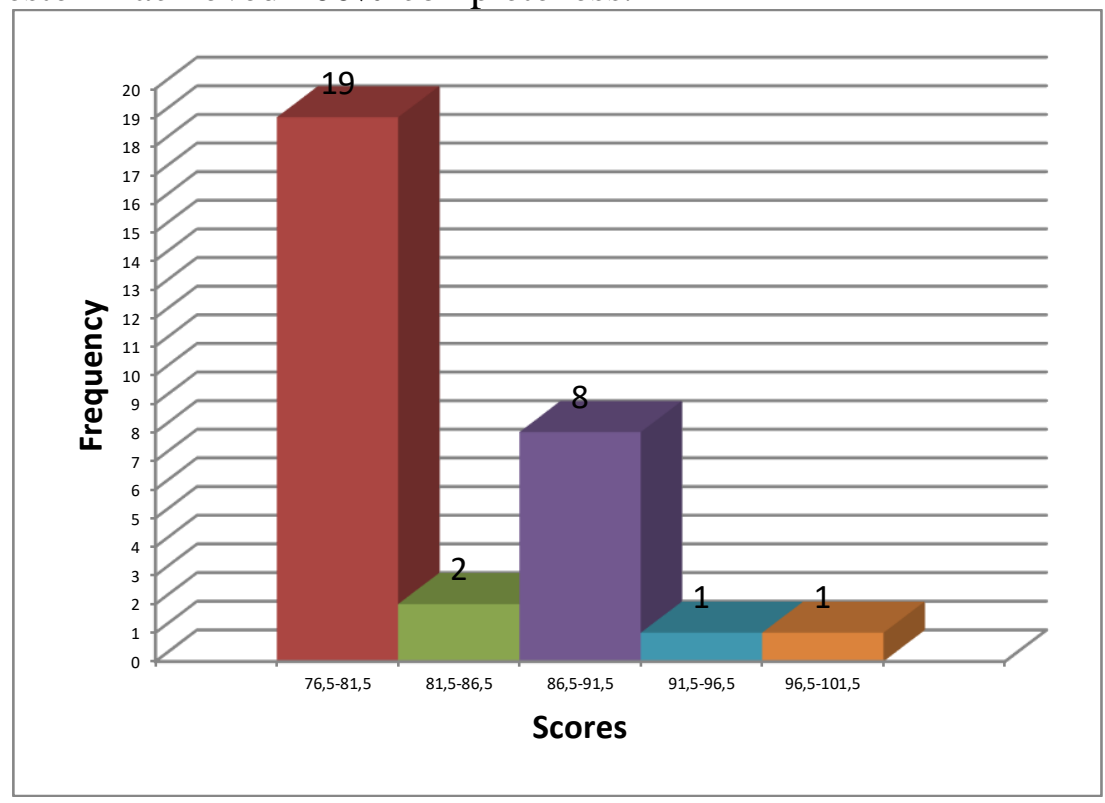

The action taken in cycle II still uses the Quantum learning model, but the teacher divides students into heterogeneous groups based on achievement, gender, and social habits. This is in line with the opinion of Slavin in Etin Solihatin (2009: 4). According to him, heterogeneous division of groups is intended so that group members can work together and can transmit knowledge to each other. Stubborn and indifferent students become more focused on learning, and student achievement increases.

In cycle II the learning outcomes increased when compared to cycle I. This is indicated by an increase in the grade average value from 78.52 to 82.29 . The percentage of students who have reached KKM in the second cycle also increased by $16 \%$, from $84 \%$ in the first cycle to $100 \%$ in the second cycle. The Quantum learning model used in Cycle II is more effective than in Cycle I because the teacher is more intensive in providing guidance to study groups in drawing conclusions and motivating students to make presentations so that student activity tends to increase compared to Cycle I. Besides students are given guidance and motivation, the teacher also rewards active groups. This can increase students' motivation to be more active in group activities including discussions in working on questions and presentations. This is in line with the opinion of Syaiful Bahri Djamarah \& Aswan Zain (2002: 168-176) knowing the results that have been done by students and gift giving is a form of motivation that can be used to maintain students' interest in the subject matter 
provided. The data generated in cycle II turned out to have met the success of the study, so the study did not need to proceed to the next cycle.

\section{Conclusion}

Based on the results of research and discussion of the application of the Quantum learning model to improve the ability to read text in grade VIII.3 students at SMP Negeri 12 Bintan, it can be concluded that the implementation of the Quantum learning model can improve students' ability to read text. This is indicated by an increase in reading skills from pre-cycle which only averaged 75.23 to 78.52 in the first cycle, while the percentage of completeness increased from $35 \%$ to $84 \%$. Moreover, in cycle II, with the improvement of Quantum learning accompanied by encouragement from teachers and guidance in groups to actively ask questions, feedback, reinforce, and divide heterogeneous groups, further increasing the ability to read text in class VIII.3 Grade point average the class increased to 82.29, and the percentage of completeness increased to $100 \%$.

The study also suggests teachers to learn by using the Quantum learning model which is not merely bringing the real world of students into the classroom. Here the teacher is required to be more creative in varying learning methods, guiding students to be more active in providing feedback, to bring up contextual problems more varied, and to direct students to be more active in learning and discussing groups. For other researchers who are interested in conducting research using the Quantum learning model, you are expected to conduct further research on other aspects of English learning by using the Quantum learning model and can apply it to different subjects.

\section{References}

Abdurrahman, Mulyono. 1996. Pendidikan Bagi Anak Berkesulitan Belajar. Jakarta: Departemen Pendidikan dan Kebudayaan.

Depdiknas. 2011. Penelitian Tindakan Kelas. Jakarta: Direktorat Jendral Pendidikan Tinggi Departemen Pendidikan Nasional.

DePorter, Bobby, dkk. 1999. Quantum Teaching: Mempraktikan Quantum Learning di Kelas. Bandung: Kaifa.

Fuady, Amir, Sumarwati, dan Slamet Mulyono. 2012. "Pembuatan Peta Semantik pada Kegiatan Prabaca untuk Meningkatkan Kemampuan Memahami Bacaan Siswa Sekolah Menengah”. Basastra Jurnal Penelitian Bahasa, Sastra Indonesia dan Pengajarannya, vol. 1, nomor 1, hlm. 1-24.

Iskandarwassid dan Dadang Sunendar. 2009. Strategi Pembelajaran Bahasa. Bandung: Remaja Rosdakarya.

Modern Educators and Lexicographers. 1939. Webster's New American Detionary. New York: 140 Broadway, Books, Inc.

Rahim, Farida. 2011. Pengajaran Membaca di Sekolah Dasar. Jakarta: Bumi Aksara.

Riyanto, H. Yatim. 2009. Paradigma Biru Pendidikan. Jakarta: Fajar Interpratama Offset.

Rofi'uddin, Ahmad \& Darmiyati Zuchdi. 1999. Pendidikan Bahasa dan Sastra Indonesia di Kelas Tinggi. Jakarta: Ditjen Dikti. 
Saifudin Sau'd, Udin. 2008. Inovasi Pendidikan. Bandung: Alfabeta.

Santosa, Puji,. dkk. 2009. Materi dan Pembelajaran Bahasa Indonesia SD. Jakarta: Universitas Terbuka.

Silohatin, Etin. 2009. Cooperative Learning analisis model pembelajaran IPS. Jakarta: PT Bumi Aksara.

Soedarso. 2002. Speed Reading: Cara Membaca Cepat yang Efektif dan Efisien. Jakarta: PT. Gramedia Pustaka Utama.

Somadoyo, Samsu. 2011. Strategi dan Teknik Pembelajaran Membaca. Yogyakarta: Graha Ilmu.

Susiani, Ketut., Nyoman Dantes \& I Nyoman Tika. 2013. Pengaruh Model Pembelajaran Quantum Terhadap Kecerdasan Sosio-emosional dan Prestasi Belajar IPA Siswa Kelas V SD di Banyuning. Universitas Pendidikan Ganesha: eJurnal penelitian eksperimen, vol 3 tahun 2013.

Suyatmi. 1997. Membaca I. Surakarta: UNS Pres.

Syaiful Bahri Djamarah dan Aswan Zain. 2002. Strategi Belajar Mengajar, Jakarta: Rineka Cipta.

Tarigan, Djago dan H.G. Tarigan. 2005. Teknik Pengajaran Keterampilan Berbahasa. Bandung: Angkasa.

Tim Prima Pena. Kamus Besar Bahasa Indonesia. Penerbit: Gita Media Press.

Wiryodijoyo, Suwaryono. 1999. Membaca: Strategi Pengantar dan Tekniknya. Jakarta: Depdikbud Direktorat Jendral Pendidikan Tinggi Proyek Pengembangan Lembaga Pendidikan Tenaga Kependidikan.

Wojowasito. 1982. Kamus Umum Lengkap Inggris Indonesia - Indonesia Inggris. Malang: Delta Citra Grafindo.

Yonata, Fadhila. (2018). The Effect of Applying The Talk-to-The Text Strategy on Students' Reading Comprehension in Narrative Text. Philosophica, 1(1), pp: 12-19.

Zuchdi, Darmiyati \& Budiasih. 1996/1997. Pendidikan Bahasa dan Sastra Indonesia di Kelas Rendah. Jakarta: Ditjen Dikti. 